\author{
Немченко В.В. \\ доктор економічних наук, профресор \\ E-mail: annem2956@gmail.com \\ Зеленяк В.В. \\ аспірант \\ кафредра обліку та аудиту \\ Одеська національна академія харчових технологій \\ вул. Канатна, 112, г. Одеса, Україна, 65039 \\ E-mail: zelenyak-vasily@mail.ru
}

\title{
РИЗИКИ ІННОВАЦІЙНО-ІНВЕСТИЦІЙНОЇ ДІЯЛЬНОСТІ ПІДПРИЄМСТВА
}

\begin{abstract}
Розглянуто інноваційно-інвестиційний процес як засіб розвитку інноваційної діяльності підприємства шляхом залучення інвестицій. Виділено внутрішні та зовнішні загрози інноваційноінвестиційного процесу в системі економічної безпеки підприємства. Досліджено основні принципи та напрями державної інноваційної політики. Виділено фрактори її впливу на зниження ризиків економічної безпеки підприємства.
\end{abstract}

Ключові слова: економічні ризики, інновації, інвестиції, інноваційно-інвестиційна діяльність, економічна безпека підприємства, державна політика.

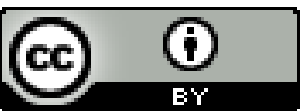

This work is licensed under a Creative Common
http://creativecommons.org/licenses/by/4.0/
Постановка проблеми та її зв'язок з важливими науковими та практичними задачами. Розвиток сучасного економічного суспільства все більше потребує використання прогресивних форм та методів здійснення господарської діяльності, які б сприяли зростанню конкурентоспроможності та ефективності вітчизняного виробництва. 3 огляду на це впровадження новітніх технологій $є$ перспективним напрямом розвитку підприємництва, а залучення інвестиційних коштів гарантує реальність реалізації поставлених інноваційних завдань.

Однак інноваційно-інвестиційний процес на будь-якому підприємстві супроводжується певними ускладненнями, які пов'язані із загрозами його економічній безпеці та ефективності. Особливо такі загрози посилюються за відсутності дієвої державної політики щодо підтримки розвитку інновацій.

У зв'язку із вищезазначеним виявлення ймовірних ризиків інноваційно-інвестиційної діяльності та розробка заходів щодо їх знешкодження або пом'якшення негативного впливу і досі залишається актуальним завданням.

Аналіз останніх публикацій 3 проблеми. Наукова спільнота сучасності жваво обговорює питання впровадження інновацій, залучення інвестицій, управління економічними загрозами діяльності. Так питанням економічних ризиків присвячено роботи Базилевича В.Д. [1], Джонса Д.Х. [2], Вербицької Г.Л. [3], Глущенко В.В. [4], Ілляшенка С.М. [5] та ін. Необхідно відзначити, що підходи авторів до визначення поняття ризику та до його класифікації різняться.
До того ж більшого висвітлення потребують проблеми, пов'язані із загрозами розвитку саме інноваційного процесу та із недостатнім рівнем підтримки інноваційно-інвестиційної діяльності на рівні держави.

Формулювання цілей дослідження. До складу цілей дослідження відносимо: систематизацію підходів до визначення категорій «інноваційноінвестиційна діяльність» та «економічний ризик», виділення внутрішніх та зовнішніх загроз інноваційно-інвестиційної діяльності підприємства, визначення принципів та напрямів державної політики щодо зниження ризиків інноваційно-інвестиційної діяльності.

Виклад основних результатів та їх обгрунтування. Інноваційний розвиток підприємства $є$ запорукою прибутковості його діяльності. Й.А. Шумпетер визначав інновацію як «втілення наукового відкриття, технічного винаходу в новій технології або в новому виді виробу» [6]. Вміле поєднання інноваційної діяльності 3 ефективним використанням залучених інвестицій забезпечує конкурентоздатність продукції підприємства на ринку товарів та послуг. Розглянемо інноваційно-інвестиційний процес як засіб розвитку інноваційної діяльності підприємства шляхом залучення інвестицій. Перш за все проаналізуємо основні підходи до визначення категорії «інноваційно-інвестиційна діяльність» (табл. 1).

Здійснення інноваційно-інвестиційного процесу пов'язано із ризиками в різних сферах діяльносTi. 
Таблиця 1

\section{Сутність категорії «інноваційно-інвестиційна діяльність»*}

\begin{tabular}{|c|c|c|}
\hline Автор & Сутність категорії & Примітки [12] \\
\hline Іванов М.Н. & $\begin{array}{l}\text { Інноваційно-інвестиційна діяльність - це системний } \\
\text { процес, що відображає комплексне забезпечення взає- } \\
\text { модії між виробництвом, інноваціями та інвестиціями } \\
\text { на рівні регіону за рахунок інтеграції зв’язків як «зни- } \\
\text { зу», від підприємств, так і «згори», від центру, з метою } \\
\text { досягнення соціально-економічного ефекту розвитку } \\
\text { регіону [7] }\end{array}$ & $\begin{array}{l}\text { Недолік: не зовсім коректне } \\
\text { застосування «забезпечення», } \\
\text { яке носить характер явища, а не } \\
\text { процесу, що притаманна «дія- } \\
\text { льності» }\end{array}$ \\
\hline $\begin{array}{l}\text { Вядрова I.М., } \\
\text { Пашова С.М. }\end{array}$ & $\begin{array}{l}\text { Інноваційно-інвестиційна діяльність - сукупність прак- } \\
\text { тичних дій інвесторів та інноваторів, направлених на } \\
\text { реалізацію інвестицій в інноваційній сфері [8] }\end{array}$ & $\begin{array}{l}\text { Позитивний момент: необхід- } \\
\text { ність об'єднання зусиль іннова- } \\
\text { тора та інвестора, які іноді мо- } \\
\text { жуть бути уособлені одним } \\
\text { суб'єктом }\end{array}$ \\
\hline Давідов М.В. & $\begin{array}{l}\text { Інвестиційно-інноваційна діяльність підприємств - це } \\
\text { складна динамічна система, що грунтується на компле- } \\
\text { ксі фінансово-економічних важелів і стимулів, яка по- } \\
\text { єднує технологічні процеси та форми організації вироб- } \\
\text { ництва на основі найновіших досягнень науки і техніки } \\
\text { із формами їх багатостороннього фінансування [9] }\end{array}$ & $\begin{array}{l}\text { Основним завданням є пошук } \\
\text { та ефективне використання фі- } \\
\text { нансових ресурсів для доведен- } \\
\text { ня наукових, технічних ідей і } \\
\text { розробок до конкретної проду- } \\
\text { кції та технології, які мають } \\
\text { попит на ринку }\end{array}$ \\
\hline Задніпрянна Т.С. & $\begin{array}{l}\text { Інноваційно-інвестиційна діяльність підприємства - } \\
\text { складна динамічна стохастична система, що складається } \\
\text { з різних за своєю природою процесів та в загальному } \\
\text { випадку включає: інноваційний процес (НДдКР або } \\
\text { пошук відповідних нововведень; кількісні, якісні та } \\
\text { структурні перетворення); процеси організаційно- } \\
\text { економічного, інвестиційного та соціокультурного за- } \\
\text { безпечення нововведень [10] }\end{array}$ & \\
\hline Жуков В.Р. & $\begin{array}{l}\text { Інноваційно-інвестиційна діяльність підприємства - єд- } \\
\text { ність інноваційного процесу з процесами організаційно- } \\
\text { економічного та соціокультурного забезпечення, що } \\
\text { дозволяє при створенні систем управління для різних } \\
\text { видів інновацій ураховувати сформовані граничні поєд- } \\
\text { нання окремих стратегій підприємства [11] }\end{array}$ & $\begin{array}{l}\text { Недолік: необхідність узго- } \\
\text { дження інноваційного процесу } 3 \\
\text { іншими процесами на підпри- } \\
\text { ємствами, проте не розкриває } \\
\text { сутності самого поняття «інно- } \\
\text { ваційно-інвестиційна діяль- } \\
\text { ність» }\end{array}$ \\
\hline
\end{tabular}

* узагальнено автором

Своєчасне виявлення можливих загроз інноваційно-інвестиційного розвитку сприяє зростанню економічної безпеки підприємства. Безпека інноваційно-інвестиційної діяльності полягає у виявленні та протидії внутрішніх та зовнішніх загроз ефективній діяльності підприємства харчової промисловості 3 метою забезпечення росту рентабельності бізнесу та реалізації завдань статутної діяльності підприємства, а також реалізації продовольчої програми країни.

Статистичні дослідження дозволяють виявити основні загрози інноваційно-інвестиційної діяльності в реальному секторі економіки України, зокрема [13]:
- нестача власних коштів $(80,1$ \% обстежених підприємств);

- великі витрати на нововведення (55,5 \%);

- недостатня фінансова підтримка держави $(53,7 \%)$;

- високий економічний ризик (41\%);

- тривалий строк окупності нововведень

- відсутність коштів у замовників (33,3\%).

Сутність категорії «економічний ризик» розглянуто в таблиці 2.

\section{Сутність категорії «економічний ризик»*}

\begin{tabular}{|c|l|}
\hline \multicolumn{1}{|c|}{ Автор } & \multicolumn{1}{|c|}{ Сутність категорії } \\
\hline Базилевич В.Д. & $\begin{array}{l}\text { економічний ризик - це об'єктивно-суб’єктивна категорія у діяльності суб'єктів господа- } \\
\text { рювання, що пов’язана 3 подоланням невизначеності та конфліктності в ситуації неминучо- } \\
\text { го вибору [1] }\end{array}$ \\
\hline
\end{tabular}


Продовження таблиці 2

\begin{tabular}{|c|c|}
\hline Джонс Д.Х. & $\begin{array}{l}\text { ризик - це загроза того, що яка-небудь подія, дія або нездатність до дії несприятливо по- } \\
\text { значаться на спроможності організації ефективно реалізувати іiі бізнес-завдання та } \\
\text { стратегічні плани [2] }\end{array}$ \\
\hline Вербицька Г.Л. & $\begin{array}{l}\text { ризик - не тільки імовірність небезпеки або невдачі, зняття суб’єктом господарювання не- } \\
\text { визначеності за конкретних обставин, подолання непевності і конфлікту в ситуації немину- } \\
\text { чого вибору, але й поєднання можливості досягнення як небажаних, так і особливо сприят- } \\
\text { ливих відхилень від запланованих результатів” [3] }\end{array}$ \\
\hline Глущенко В. В. & $\begin{array}{l}\text { ризик - це можливість позитивного (шанс) або негативного (збиток) відхилення в процесі } \\
\text { діяльності від очікуваних або планованих значень [4] }\end{array}$ \\
\hline Ілляшено С.M. & $\begin{array}{l}\text { інноваційний ризик - загроза втрати своїх ресурсів, недоотримання доходу чи появи додат- } \\
\text { кових витрат суб’єктами інноваційного процесу [5] }\end{array}$ \\
\hline
\end{tabular}

В табл. 3 систематизовано основні групи зов- п підприємства) інноваційно-інвестиційного процесу. нішніх та внутрішніх загроз (на рівні держави та

Таблиця 3

Внутрішні та зовнішні загрози інноваційно-інвестиційного процесу [14]

\begin{tabular}{|c|c|c|c|}
\hline $\begin{array}{c}\text { Загрози } \\
\text { інноваційно- } \\
\text { інвестиційного } \\
\text { процесу } \\
\end{array}$ & Загрози зовнішні & $\begin{array}{l}\text { Загрози внутрішні } \\
\text { (на рівні держави) }\end{array}$ & $\begin{array}{c}\text { Загрози внутрішні } \\
\text { (на рівні підприємства) }\end{array}$ \\
\hline 1. Політичні & $\begin{array}{l}\text { Нестабільність політичних } \\
\text { зв’язків (зовнішня агресія, відсу- } \\
\text { тність підтримка світової спіль- } \\
\text { ноти тощо) }\end{array}$ & $\begin{array}{l}\text { Форс-мажорні обставини } \\
\text { (війна, стихійні лиха, те- } \\
\text { хногенні аварії тощо) }\end{array}$ & $\begin{array}{l}\text { Відсутність чіткої ін- } \\
\text { новаційної політики }\end{array}$ \\
\hline 2. Економічні & $\begin{array}{l}\text { Зміна політико-економічної орі- } \\
\text { єнтації країни-інвестора }\end{array}$ & $\begin{array}{l}\text { Нестабільність законо- } \\
\text { давства щодо інвестицій- } \\
\text { но-інноваційного процесу }\end{array}$ & $\begin{array}{l}\text { Відсутність стабільних } \\
\text { зв’язків із потенційни- } \\
\text { ми інвесторами інно- } \\
\text { ваційних процесів } \\
\text { Низький рівень техні- } \\
\text { ко-технологічного по- } \\
\text { тенціалу }\end{array}$ \\
\hline 3. Інформаційні & $\begin{array}{l}\text { Втрата позицій у зв’язку із дія- } \\
\text { льністю міжнародної економіч- } \\
\text { ної розвідки }\end{array}$ & $\begin{array}{l}\text { Відсутність інформацій- } \\
\text { ної підтримки, низький } \\
\text { рівень моніторингу }\end{array}$ & $\begin{array}{l}\text { Низький рівень інфор- } \\
\text { маційної безпеки біз- } \\
\text { несу }\end{array}$ \\
\hline 4. Фінансові & Фінансова криза & $\begin{array}{l}\text { Нестабільність вітчизня- } \\
\text { ної валюти, фінансова } \\
\text { криза }\end{array}$ & $\begin{array}{l}\text { Нестабільний фінансо- } \\
\text { вий стан підприємства }\end{array}$ \\
\hline 5. Кадрові & Витік кадрів за кордон & $\begin{array}{l}\text { Низький рівень фахової } \\
\text { підготовки спеціалістів в } \\
\text { галузі інновацій }\end{array}$ & $\begin{array}{l}\text { Низький рівень кадро- } \\
\text { вого потенціалу підп- } \\
\text { риємства }\end{array}$ \\
\hline
\end{tabular}

Інноваційно-інвестиційний процес потребує формування ефективної державної політики.

Основними принципами державної інноваційної політики є:

- орієнтація на інноваційний шлях розвитку економіки України;

- визначення державних пріоритетів інноваційного розвитку;

- формування нормативно-правової бази у сфері інновацій;

- створення умов для збереження, розвитку й використання вітчизняного науково-технічного та інноваційного потенціалу;

- забезпечення взаємодії науки, освіти, виробництва, фінансово-кредитної сфери у розвитку інноваційної діяльності;
- ефективне використання ринкових механізмів для сприяння інноваційній діяльності, підтримка науково-виробничої сфери;

- здійснення заходів на підтримку міжнародної науково-технологічної кооперації, трансферу технологій, захист вітчизняної продукції навнутрішньому ринку та іiі просування на зовнішній ринок;

- фінансова підтримка, здійснення сприятливої кредитної, податкової імитної політики у сфері інноваційної діяльності;

інфраструктури; сприяння розвитку інноваційної

- інформаційне забезпечення суб'єктів інноваційної діяльності; 
діяльності.

- підготовка кадрів у сфері інноваційної

Державне регулювання інноваційної діяльності здійснюється шляхом:

- визначення i підтримки пріоритетних напрямів інноваційної діяльності державного, галузевого, регіонального і місцевого рівнів;

- формування i реалізації державних, галузевих, регіональних і місцевих інноваційних програм;

- створення нормативно-правової бази та економічних механізмів для підтримки i стимулювання інноваційної діяльності;

- захисту прав та інтересів суб'єктів інноваційної діяльності;

- фінансової підтримки виконання інноваційних проектів;

- стимулювання комерційних банків та інших фінансово-кредитних установ, що кредитують виконання інноваційних проектів;

- встановлення пільгового оподаткування суб'єктів інноваційної діяльності;

- підтримки функціонування i розвитку сучасної інноваційної інфраструктури.

Контроль інноваційно-інвестиційної діяльності здійснюється на рівні [14]:

- держави (державний контроль);

- корпоративного управління (корпоративний контроль);
- потенційних інвесторів (незалежний контроль - аудит).

На наш погляд, слід виділити фактори негативного впливу державної інноваційної політики на ризики економічної безпеки підприємства:

- неправильно обрана стратегія;

- слабка система регулювання;

- недоліки в системі координування;

- помилки податкового стимулювання;

- неефективна кредитна підтримка;

- слабка система державного контролю

Навпаки, правильно обрана стратегія щодо напрямку інноваційного розвитку, систем регулювання, координування, пільгової підтримки, фінансування та контролю сприятиме зниженню економічних ризиків та зростанню інноваційно-інвестиційної активності підприємств України.

Висновки та перспективи подальших досліджень. Таким чином, ризики інноваційноінвестиційної діяльності є взаємозалежними від інноваційної політики самого підприємства і інноваційноінвестиційної політики держави в цілому. Основним напрямом подальшого розвитку інновацій у сучасному суспільстві $\epsilon$ не тільки пошук заходів, які будуть сприяти зниженню ймовірних ризиків їх розробки та реалізації. Найбільш важливим $є$ забезпечення збалансованості інтересів підприємства, яке здійснює інноваційну діяльність, інвестора, держави та споживачів інноваційного продукту.

\section{Литература}

1. Історія економічних учень : підручник / За ред. В. Д. Базилевича. - 3-те вид., випр. і доп. - У 2 ч. - Ч. 1. - К. : Знання. - 2006. $-582 \mathrm{c}$.

2. Джонс Д.Х. Руководство для директоров // «Ассоциация Корпоративных Казначеев». - Великобритания. - 1998. $-348 \mathrm{c}$.

3. Вербицька Г.Л. Методичні основи оцінки економічного ризику в діяльності підприємств : автореф. дис. на здобуття наук. ступеня канд. екон. наук : спец. 08.06.01 «Економіка, організація і управління підприємствами» / Г.Л. Вербицька. - К.: Національний транспортний університет. - 2005. -19 с.

4. Глущенко В.В. Управление рисками. Страхование. / В. В. Глущенко. - г. Железнодорожный Моск. обл.: ТОО НПЦ «Крылья». - 1999. - 336 с.

5.Ілляшено С.М. Інноваційний менеджмент: підручник / С.М. Ілляшенко. - Суми: ВТД «Університетська книга». - 2010. -334 с.

6. Шумпетер Й. Теория эономического развития. Капитализм, социализм, демократия / Й. Шумпетер. М.: Эксмо. - 2007. - 234 С.

7.Іванов М.Н. Підвищення ефективності функціонування регіональних економічних систем на основі активізації інноваційно-інвестиційної діяльності / М.Н. Іванов // Схід: Спецвипуск. - 2011. - № 1 (108). - С. 7982.

8.Вядрова I. М. Система фінансового забезпечення інноваційного-інвестиційного розвитку в Україні та можливості ії активізації в сучасних економічних умовах / І. М. Вядрова, С. М. Пашова // Вісник Університету банківської справи НБУ. - 2011. - № 1 (10). - С. 121-126.

9.Давідов М. В. Організаційно-фінансове забезпечення інноваційної діяльності суб'єктів господарювання / М. В. Давідов // Актуальні проблеми економіки. - 2008. - № 9. - С. 92-97.

10.Задніпрянна Т. С. Управління інноваційно-інвестиційною діяльністю підприемства Т. С. Задніпрянна // Економічний вісник Донбасу. - 2011. - № 1 (23). - С. 203-205. 
11.Жуков В. Р. Управление инновационно-инвестиционной деятельностью предприятия / В. Р. Жуков. - Донецк: Норд-Пресс. - 2006. - 147 с.

12.Блудова Т.В. Моделювання інноваційно-інвестиційної діяльності в контексті економічної безпеки підприємства / Т.В. Блудова, В.В. Токар // Електронне наукове фахове видання «Ефективна економіка». - №2. - 2013. [Електронний ресурс] - Режим доступу: http://www.economy.nayka.com.ua/?op=1\&z=1826

13.Киян Н.О. Розвиток інноваційно-інвестиційних процесів як фактора суттєвого підвищення ефективності гірничодобувного виробництва / Н.О. Киян // Вісник Криворізького економічного інституту КНЕУ. 2010. - №3 (23). - С. 93-99.

14.Зеленяк В.В. Контроль в системі інноваційно-інвестиційної діяльності державна політика та сприяння укріпленню позицій фінансово-економічної безпеки / В.В. Зеленяк, В.В. Немченко // Обліково-аналітичне забезпечення в умовах управління фінансово-економічною безпекою підприємства: монографія під ред. проф. Немченка В.В. - Одеса: Фенікс. - 2015. - 360 с. - С. 261-270.

\author{
Немченко В.В. \\ доктор экономических наук, профессор \\ E-mail: annem2956@gmail.com \\ Зеленяк В.В. \\ аспирант \\ кафедра учета и аудита \\ Одесская национальная академия пищевых технологий \\ ул. Канатная, 112, г. Одесса, Украина, 65039 \\ E-mail: zelenyak-vasily@mail.ru
}

\title{
РИСКИ ИННОВАЦИОННО-ИНВЕСТИЦИОННОЙ ДЕЯТЕЛЬНОСТИ ПРЕДПРИЯТИЯ
}

Инновационное развитие предприятия является залогом прибыльности его деятельности. Умелое сочетание инновационной деятельности с эффективным использованием привлеченных инвестиций обеспечивает конкурентоспособность продукции предприятия на рынке товаров и услуг. Инновационно-инвестиционный процесс рассматривается в данной статье как средство развития инноваций путем привлечения инвестиций.

Осуществление инновационно-инвестиционного процесса связано с рисками в различных сферах деятельности. Своевременное выявление возможных угроз инновационно-инвестиционного развития способствует росту экономической безопасности предприятия. В статье рассмотрено понятие сущности инновационно-инвестиционного процесса, проанализировано его влияние на экономическую безопасность предприятия. Проведена систематизация понятия экономического риска. Авторами выделены внутренние и внешние угрозы инновационно-инвестиционного процесса в системе экономической безопасности предприятия. Выделены внутренние угрозы, связанные с деятельностью государства и деятельностью самого предприятия.

К основным угрозам, связанных с деятельностью предприятия отнесены: отсутствие четкой инновационной политики, отсутствие стабильных связей с потенциальными инвесторами инновационных процессов, низкий уровень технико-технологического потенциала, низкий уровень информационной безопасности бизнеса, нестабильное финансовое состояние предприятия, низкий уровень кадрового потенциала предприятия. Авторами сделан вывод о необходимости организации на предприятии эффективной системы анализа и контроля движения и состояния производственного потенциала предприятия.

Успех реализации инновационных программ развития предприятия напрямую зависит от поддержки государства. В данной статье исследованы основные принципы и направления государственной инновационной политики, авторами выделены факторы государственной инновационной политики, влияющие на снижение рисков экономической безопасности предприятия. 
Авторами сделан вывод, что риски инновационно-инвестиционной деятельности взаимосвязаны от инновационной политики самого предприятия и инновационно-инвестиционной политики государства. Основным направлением дальнейшего развития инноваций в современном обществе является не только поиск мер, которые будут способствовать снижению вероятных рисков их разработки и реализации. Наиболее важным является обеспечение сбалансированности интересов предприятия, осуществляющего инновационную деятельность, инвестора, государства и потребителей инновационного продукта.

Ключевые слова: экономические риски, инновации, инвестиции, инновационноинвестиционная деятельность, экономическая безопасность предприятия, государственная политика.

\author{
Nemchenko B.B. \\ Doctor of Economics, Professor \\ E-mail: annem2956@gmail.com \\ Zelenyak V.V. \\ Postgraduate student \\ Department of Accounting and Auditing \\ Odessa National Academy of Food Technologies \\ Kanatna str., 112 , Odessa, Ukraine, 65039 \\ E-mail: zelenyak-vasily@mail.ru
}

\title{
RISKS OF INVERSTING IN THE INNOVATION OF THE COMPANY
}

Innovation is the key to the development of enterprise profitability. Skillful combination of innovation with effective use of the investments provides a competitive of product on the market of goods and services. This article innovation and investment process as a means of innovation of the company by attracting investment. Innovative investment process is considered in this article as a tool for innovation by attracting investment.

Implementation of innovative investment process is associated with risks in different areas. Timely identification of possible threats to innovation and investment development contributes to economic security. Timely identification of possible threats to innovation and investment development contributes to economic security. The authors conducted the systematization of the concept of economic risk. The authors identify internal and external threats to innovation and investment process in the system of economic security. There are internal threats associated with the activities of the state and activity of the enterprise.

The main internal threats that are associated with the activities of the company include: lack of clear innovation policies, lack of stable relations with potential investors innovative processes, low level of technical and technological capacity, low level of information security business, financial condition unstable, low potential of the company. The authors concluded that enterprises should organize an effective system of analysis and control of the movement and status of the production potential of the company.

The success of the innovative programs of the company depends on state support. In this article the basic principles and directions of innovation policy. The authors distinguish innovation policy factors that influence the risk reduction of economic security.

The authors concluded that the risks of innovation and investment activities are interdependent are the innovation policy of the enterprise and innovative investment policy. The main direction of further development of innovations in modern society is not only search for activities that will help to reduce possible risks of their development and implementation. The most important is to ensure a balance of interests of the company, which carries out innovation, investors, state and consumers innovative product.

Keywords: economic risks, innovation, investment, innovation activities and investments, economic security, public policy. 


\section{References}

1. Bazylevych, V. (2006). Istoriia ekonomichnykh uchen (3rd ed., p. 582). Kyiv: Znannia.

2. Dzhons, D. (1998). Rukovodstvo dlia dyrektorov (p. 348). Velykobrytanyia: Assotsyatsyia Korporatyvnykh Kaznacheev.

3. Verbytska, H. (2005). Metodychni osnovy otsinky ekonomichnoho ryzyku v diialnosti pidpryiemstv (p. 19). Kiyv: Natsionalnyi transportnyi universytet.

4. Hlushchenko, V. (1999). Upravlenye ryskamy. Strakhovanye (p. 336). Zheleznodorozhnyi: TOO NPTs «Krylia».

5. Illiashenko, S. (2010). Innovatsiinyi menedzhment (p. 334). Sumy: VTD «Universytetska knyha».

6. Shumpeter, I. (2007). Teoryia eonomycheskoho razvytyia. Kapytalyzm, sotsyalyzm, demokratyia (p. 234). Moskva: Eksmo.

7. Ivanov, M. (2011). Pidvyshchennia efektyvnosti funktsionuvannia rehionalnykh ekonomichnykh system na osnovi aktyvizatsii innovatsiino-investytsiinoi diialnosti. Skhid, (1 (108)), 79-82.

8. Viadrova, I., \& Pashova, S. (2011). Systema finansovoho zabezpechennia innovatsiinoho-investytsiinoho rozvytku v Ukraini ta mozhlyvosti yii aktyvizatsii v suchasnykh ekonomichnykh umovakh. Visnyk Universytetu Bankivskoi Spravy NBU, 1(10), 121-126.

9. Davidov, M. (2008). Orhanizatsiino-finansove zabezpechennia innovatsiinoi diialnosti sub'iektiv hospodariuvannia. Aktualni Problemy Ekonomiky, (9), 92-97.

10. Zadniprianna, T. (2011). Upravlinnia innovatsiino-investytsiinoiu diialnistiu pidpryiemstva. Ekonomichnyi Visnyk Donbasu, 1 (23), 203-205.

11. Zhukov, V. (2006). Upravlenye ynnovatsyonno-ynvestytsyonnoi deiatelnostiu predpryiatyia (p. 147). Donetsk: Nord-Press.

12. Bludova, T., \& Tokar, V. (2013, March 27). Modeliuvannia innovatsiino-investytsiinoi diialnosti v konteksti ekonomichnoi bezpeky pidpryiemstva. Retrieved August 23, 2015, from http://www.economy.nayka.com.ua/?op=1\&z=1826

13. Kyian, N. (2010). Rozvytok innovatsiino-investytsiinykh protsesiv yak faktora suttievoho pidvyshchennia efektyvnosti hirnychodobuvnoho vyrobnytstva. Visnyk Kryvorizkoho Ekonomichnoho Instytutu KNEU, 3 (23), 93 -99.

14. Zeleniak, V., \& Nemchenko, V. (2015). Kontrol v systemi innovatsiino-investytsiinoi diialnosti derzhavna polityka ta spryiannia ukriplenniu pozytsii finansovo-ekonomichnoi bezpeky. Oblikovo-analitychne Zabezpechennia v Umovakh Upravlinnia Finansovo-ekonomichnoiu Bezpekoiu Pidpryiemstva, 261-270.

Received 17 September 2015

Approved 02 October 2015

Available in Internet 26.12.2015 